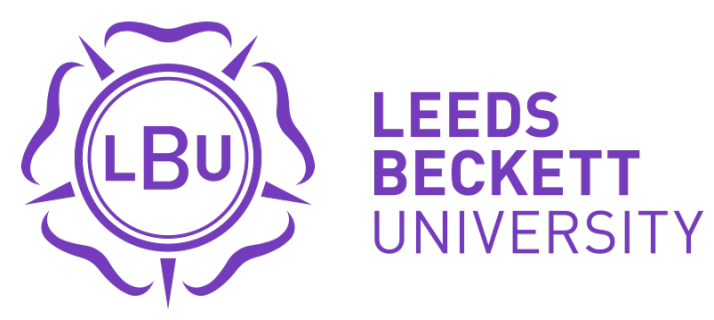

Citation:

Spracklen, K (2018) Leisure, Popular Culture and Memory: The Invention of Dark Age Britain, Wales, England, and Middle-earth in the songs of Led Zeppelin. International Journal of the Sociology of Leisure, 1 (2). pp. 139-152. ISSN 2520-8683 DOI: https://doi.org/10.1007/s41978-018-0009-7

Link to Leeds Beckett Repository record:

https://eprints.leedsbeckett.ac.uk/id/eprint/4657/

Document Version:

Article (Accepted Version)

The aim of the Leeds Beckett Repository is to provide open access to our research, as required by funder policies and permitted by publishers and copyright law.

The Leeds Beckett repository holds a wide range of publications, each of which has been checked for copyright and the relevant embargo period has been applied by the Research Services team.

We operate on a standard take-down policy. If you are the author or publisher of an output and you would like it removed from the repository, please contact us and we will investigate on a case-by-case basis.

Each thesis in the repository has been cleared where necessary by the author for third party copyright. If you would like a thesis to be removed from the repository or believe there is an issue with copyright, please contact us on openaccess@leedsbeckett.ac.uk and we will investigate on a case-by-case basis. 


\section{Leisure, Popular Culture and Memory: The Invention of Dark Age Britain, Wales, England, and Middle-earth in the songs of Led Zeppelin}

\section{Introduction}

Popular music and culture are sites of interest to leisure theorists and sociologists of leisure, because they are places of leisure where meaning is made (Spracklen 2009, 2011, 2013). This culture-as-leisure focus is often the space in which contestations of meaning can take place about history, memory and identity (Spracklen 2011). In the period of high modernity, and in the process of establishing the imperial nation-state of Great Britain, historians, archaeologists and enthusiastic amateurs searched high and low for material evidence and primary sources from what was called the Dark Ages (Alexander 2007; Bloch and Nichols 1996; Cantor 1991). There is a gap in knowledge about this past, and all discussion rests on finding meaning in fading inscriptions, or dark earth, or trusting completely the writings of the few primary sources from the time, and especially the most important writers of the period: Bede and Gildas. For classical historians reading Bede and Gildas alongside Roman sources, the Britannia of the Roman Empire was abandoned by its imperial rulers to decades of decline, with the people of Britain, the British, dying in plagues, famines and in the cruel invasions of the founders of what became Anglo-Saxon England: the Saxons, Jutes, and Angles (Alexander 2007). These Germanic invaders in this story pushed the remnants of the British peoples to the north and west, where they became the Welsh and the Cornish, people speaking Celtic languages. The story of England told by the historians of the nineteenthcentury and the twentieth-century saw the Saxon English seeing off the Celts, then the Vikings, but losing to the Normans.

The search for an identity and history for the nation for Great Britain was based on normative beliefs of Englishness as a fusion of Norman and Saxon. Or in popular memory 
England was re-constructed as the land of the Anglo-Saxons, and its folk and race those people who had lost out to the Normans. Or the Saxons, in turn, were rejected as interlopers, by the popular memory of Welsh nationalists, and by others who believed Britain was essentially Celtic (Armstrong and Hodges 2014; Wickham 2005). In the nineteenth-century the debates about Britannia, Wales, England and their place in the story of Great Britain were underpinned by the literary texts that survived, and drew on the modern language of nationalism and race. That is, the English were identified as Germans or Aryans, superior in body and mind to the 'swarthy' Welsh or 'Britons', who lost the Darwinian struggle to build a sustainable nation in the second half of the first millennium. As archaeologists started to dig methodically into the earth and into the Roman sites scattered around the island of old Britannia, they easily identified layers of destruction in the towns as evidence of the destructive nature of the Saxon invasions. Dark earth layers were found above these destruction layers that seemed to indicate that no one had lived in these sites for hundreds of years following their destruction. But other archaeologists questioned this narrative., and claimed that at many sites there was no sign of destruction, only re-use, and the cultural artefacts that were identified as being clearly Saxon or clearly Celtic were not so clear after all (Wickham 2005). In the twentieth-century, then, there were differing opinions about the nature of England, of Wales and Britain relating to the origins of Wales and the origins of England. In the absence of confirmatory evidence, people on either side of the debate took to searching for the magic artefact or inscription or source that would prove the decline of the Celts and the victory of the Saxons, or the continuity of Britishness and Romano-British culture.

Of course, these debates in the twentieth-century happened in universities and schools. But they crossed over into popular culture and leisure, especially in the post-war period of the second half if the twentieth-century, when Englishness, Welshness and 
Britishness were being re-appraised with the decline of the British Empire, and the rise of global capitalism and the new world order of the Cold War (Darwin 2009). The debates were taken up by English nationalists who wanted to confirm modern Englishness was exclusively related by blood and heritage to the Anglo-Saxons, who brought their German genes to stay (Schwarz 2005). But the debates were also taken up by people who wanted to find some Celticness or Welshness to their English heritage and culture (Kandt, Cheshire, and Longley 2016). In the work of J. R. R. Tolkien ${ }^{1}$, the debates literally crossed over. As I will show below, the problem of Englishness, place and myth led Tolkien to write his Middle-earth stories in his leisure time. At the same time, the problem of Welshness or Britishness saw a growth in the interest in Arthurian traditions and a tourist interest in the Celtic fringe of Britain (Hale 2001; Robb 1998). In this paper, I want to look at that post-Second World War crossover as it relates directly to the ideas in the heads of rock musicians. In this paper, I will show how the songs and album covers of Led Zeppelin, and their film The Song Remains the Same (Clifton and Massot 1976), draw upon both the work of Tolkien and the Arthurian traditions to construct ideas of masculine belonging in some mythological medieval time and place. While this constriction is idiosyncratic to the artists, they are drawing on and justifying the wider problem of England, Wales and Britain. Before I focus Led Zeppelin's work in more details, it is necessary to review Tolkien's work and his impact, and also the Arthurian tradition as it was commonly understood. Before I do any of that historical analysis, it is necessary to situate the research in its broader theoretical framework, and to say something about methodology.

Culture-as-leisure refers to the claim by Spracklen $(2009,2011)$ that popular culture is a space or form of human activity which is constructed - and contested - in leisure time and

\footnotetext{
${ }^{1}$ In particular, The Hobbit (Tolkien 1937), The Lord of the Rings, originally published in three volumes (Tolkien 1954a, 1954b, 1955), The Silmarillion (Tolkien 1977), and the earlier unpublished writings (the Book of Lost Tales especially) that deal with the early 'English' mythos and what later came to be called the First Age (Tolkien 1983, 1984, 1985, 1986, 1987).
} 
leisure space. Leisure theorists such as Parker (1971) have argued that leisure has the potential to be freely chosen and liberating, but all too often it is the product of social and political constraints. I have made the same point in Spracklen $(2009,2011,2013)$, where I have argued that leisure comes in two forms: communicative leisure freely chosen, and instrumental leisure imposed by hegemonic capitalism and nation-states. Culture-as-leisure, then, is always in the process of being made, and always a product of Adorno's (1991) culture industries. National identity is one hegemonic construction in culture-as-leisure, but it always intersects over forms of hegemony. In this paper, then my theoretical framework extends to the intersection of hegemonic masculinity (Connell 1987, 1995), which is ever present - if challenged - in all modern leisure (Watson and Scraton 2013). This is the claim I have made in previous research on folk metal and black metal (Spracklen 2015, 2017): culture-as-leisure constructs national identity and hegemonic masculinity.

The methodological approach is partly historical, and partly a semiotic analysis of forms of culture, such as song lyrics. As with Spracklen (2017), I have used Discourse Tracing (LeGreco and Tracy 2009) as a frame to make sense of the meaning-making and the myth-making at the micro, meso and macro levels.

\section{The Matter of Britain: From King Arthur to Aragorn, King of Gondor}

When Parliament was being re-built in Victorian re-built, artwork was deliberately chosen to reflect the Victorian-Gothic fantasy fairy-tale design of the building itself. Parliament had to stand for the glory and splendour of Great Britain, its Empire, and the Victorian belief in the rightness of Englishness and English men. As the Parliament web-site explains:

A popular and well known tale, the Legend of King Arthur was chosen for the walls of the Queens Robing Room. It was proposed by the artist William Dyce and 
provided the opportunity for him to illustrate what the Victorians regarded as the starting point of their history. There had been a revival of interest in Arthur and his court and he was regarded as a national hero. Working from Malory's epic romance of King Arthur, Dyce chose the subjects by concentrating on the virtues displayed by the Knights as part of the ancient code of chivalry.

(http://www.parliament.uk/worksofart/collection-highlights/british-history/the-legendof-king-arthur, accessed 19 April 2017)

The Victorian British saw King Arthur through the lens of the epic narrative of Malory's Le Morte D'Arthur. ${ }^{2}$ This King was the true knight, Christian and valorous, who created the Knights of the Round Table and built Camelot. This is the King Arthur captured in the epic poetry of Alfred, Lord Tennyson: Arthur the gentleman knight whose commitment to morality and duty reflects that of the British ruling classes, the king who cares for his country and his destiny and does the right thing even though he dies defending his land (Armstrong and Hodges 2014; Barber 2002; Ingham 2015). The version of Arthur sculpted on the walls of the British Parliament and in the verses of Tennyson's Idylls of the King is the Arthur who became a myth of England and Englishness in many re-tellings and in popular culture in the twentieth century, transformed in the collective memory through Hollywood's fixation with knights in shining armour, jousts and the make-believe worlds of the American renaissance fairs (Aronstein and Corner 2001; Bloch 1993; Finke and Shichtman 2010).

There are of course huge problems with this version of King Arthur. The Arthur of twentieth-century Hollywood and nineteenth-century Parliament murals is the Arthur of Malory, who is the Arthur of the Romantic tradition, the late-medieval French sources that use the story of Arthur as a backdrop to tales of love and chivalry (Batt 2016). These passed

\footnotetext{
${ }^{2}$ For a discussion of Malory and full references see Batt (2016).
} 
over to England and were used at the time to legitimate the rule of the Norman elites and to connect their royal claims to the older tradition of King Arthur as King of the Britons. This national hero of Great Britain, essentially a national hero of England, was (and is) actually and justifiably claimed as a national hero by the Welsh and the Cornish, who saw themselves as the Britons and the British pushed out of their homeland by the evil Saxons (Higham 2005). The Welsh Arthur appears in a handful Welsh primary sources from the end of the period as some kind of war-leader or hero, but his existence is strongly disputed, and even the references that name him such as the comment in $Y$ Gododdin that someone was no hero like Arthur are questioned (Higham 2005; Jackson 1969). The struggle over Arthur reflects the struggle over the land of the old island of Britannia, but it also reflects the cultural hybridity of Britain, Wales and England, as the Welsh and the English, ever since the first interactions between them, shared ideas, stories and artefacts (Barczewski 2000).

All this idea of hybridity and the contested status of the Arthur and the Matter of Britain is found in the work of Tolkien (Fimi 2008; Mathijs 2006). Although born in South Africa, Tolkien spent most of his formative years in the West of England, just outside the city of Birmingham in the old Saxon border region of Mercia. This was and is a liminal space between England and Wales, fought over by armies, but also travelled over by people seeking work, love and education. In his biography of Tolkien, Carpenter (1977) describes how Tolkien became fascinated by language when he saw coal trains coming through the railway lines emblazoned with the names of Welsh mines and railway stations painted on them. Tolkien was fascinated by the sound of Welsh as well as the way Welsh was constructed, and used the sound and the grammar as the basis for one of his two imagined Elf languages Sindarin (Carpenter 1977; Shippey 1982; Tolkien 1983, 1984). As he grew older, he became interested in the Arthurian tradition and even wrote a poem ('The Fall of Arthur') that was published posthumously. But he expressed a 'distaste' for Celtic mythology more generally 
(Fimi 2008; Shippey 1982), and, as we know, was drawn towards Anglo-Saxon mythology and Old English as a language of philological study. In first writing what became 'The Book of Lost Tales', Tolkien was attempting to write an English mythological cycle, similar to the Finnish Kalevala, which he wished had actually existed for English (Carpenter 1977; Shippey 1982). This mythological cycle as originally drafted in the first half of the twentieth-century was meant to be a source of identity and pride for England, as the Kalevala could be for England, and Tolkien's invention of the myth was chance to right the wrongs of history: the loss of so much Anglo-Saxon culture following the Norman invasion, and the adoption of the Arthurian tradition by the English (Ingham 2015).

We all know what happened next. Tolkien found himself in a fairly steady academic position at Oxford, where he taught Anglo-Saxon, He worked on his mythological cycle relentlessly, re-framing and re-writing it through a number of iterations to become The Silmarillion (Tolkien 1977). And he was raising his own children and entertaining them by telling stories at bedtime (Carpenter 1977). The three parts of his life merged when he wrote The Hobbit (Tolkien 1937), a story framed as a story for children, but one that drew upon the now vast mythology of the then-unpublished Silmarillion mythos, as well as ideas and names from the German and Norse myths (Rateliff 2007). Tolkien passed the manuscript of The Hobbit to a few close friends, and one of those showed it to someone who worked in publishing. The book was published and became such a success that the publishers demanded a sequel. For the next few years, and through the Second World War, Tolkien wrote The Lord of the Rings (Tolkien 1954a, 1954b, 1955). That book's publication in three volumes led to Middle-earth and its essential Englishness being admired by millions of readers around the world (Carpenter 1977; Fimi 2008; Piatti-Farnell 2015; Rateliff 2007; Shippey 2002).

For many people, the story is about nobility and blood: the story is told of the heir to the Kingdom of Gondor, Aragorn, and his triumphant return to claim what is rightfully his. 
He returns to bring peace and prosperity to Gondor and all lands of the West. Aragorn is of the race of higher men, the Numenoreans, and the human enemies of Gondor include hideously-described black-skinned Southrons and 'swarthy' Easterlings (Fimi 2008). But there are other stories to be found in the book. The hero of the tale is the hobbit Frodo, who is not a warrior at all, and who seems reluctant to hurt anyone, and he defeats Sauron by his courage in returning the Ring to the volcanic fire at the heart of Mordor, the realm of Sauron. For many young people growing up in the 1960s, the book reflected the morality of the antiwar movement, a parable of the world-destroying power of nuclear weapons and the need to get rid of them (Rosebury 2003). In the wizard-turned-bad Saruman, with his furnaces and his desire to chop down all the trees of the forest of Fangorn, other counter-cultural messages about the evils of modernity and capitalism were heard: Tolkien seemed to be aligning with the environmental politics emerging at the time (ibid.). Very quickly in the 1960s, then, Tolkien and his work became owned, as culture-as-leisure, by the counter-cultural hippy movement, who saw themselves as pipe-smoking hobbits, heroic rangers, or mystical elves (Burges 2013; Piatti-Farnell 2015).

\section{Wales and Middle-earth in Led Zeppelin}

Led Zeppelin, formed in 1968 by the seasoned professional musician Jimmy Page, were one of the biggest rock bands of their day, generating huge sales of records and concert tickets in their original incarnation. In the years following their break-up in 1980 after the death of their drummer John Bonham the band continued to sell records in their millions and became one of the biggest rock bands so far in the history of popular music. Their influence and impact has been the subject of many academic papers and books (see for example Brackett 2008; Fast 1999, 2001; Gracyk 2007). For Susan Fast (1999), Led Zeppelin's success was due to the seductive combination of the musical genius and occult flair of Jimmy Page and the naked 
sexuality of frontman and singer Robert Plant. Page was someone who dabbled in the occult and played with imagery from the work of Crowley and others; this was a way of connecting Led Zeppelin to the American blues musicians they worshipped, famously Robert Johnson who reputedly sold his soul to the Devil (Gracyk 2007). Blues is the basis for the Led Zeppelin sound, and Plant's rampant heteronormative performativity is essentially a blues masculinity perfect when he was singing in local bands in Birmingham, close to the house where Tolkien had grown up.

While Page and bass player John Paul Jones were from the south-east of England, the so-called Home Counties of the white upper-middle class, Plant and Bonham were workingclass white men from the West Midlands. Plant, Led Zeppelin's main lyricist after the debut album, was born in 1948 in West Bromwich in Staffordshire, then was brought up in Kidderminster in Worcestershire, nearer the border with Wales. In a BBC radio interview in 2010, cited on Wikipedia ${ }^{3}$, Plant admits to being fascinated as a child with Romano-British history, before he became enamoured of rock and roll and the blues (https://en.wikipedia.org/wiki/Robert_Plant, accessed 24 April 2017). Wikipedia also notes that he:

would often take summer trips to Snowdonia. Plant bought a Welsh sheep farm in 1973, and began taking Welsh lessons and looking into the mythology of the land (such as Black Book of Carmarthen, Book of Taliesin, etc.) Plant's first son, Karac, was named after the Welsh warrior Caratacus.

\footnotetext{
${ }^{3}$ Wikipedia has to be treated with caution, but it is a useful way of mapping the collective memory of the internet: what people think is the truth, and what happened (Spracklen 2014).
} 
Led Zeppelin's first album Led Zeppelin (1969a), a collage of Page originals and blues adaptations, has no reference to anything that could be definitely identified as being part of the Matter of Britain and Wales, or anything inspired by Middle-earth. There is the acoustic instrumental 'Black Mountain Side' that sounds vaguely medieval and Oriental, and the name could be a reference to the Black Mountain in the south of Wales. But this Black Mountain is not in the same area of Wales - Snowdonia - that Plant visited, in which he bought the sheep farm and where the Page and Plant retreated to write and record in 1970. It is not on the holiday route from the West Midlands into Wales, not part of the Welshspeaking heart of Wales in the north-west.

Led Zeppelin II (1969b) is the first album where Plant explores Arthurian mythology and Middle-earth. The second song, 'What Is And What Should Never Be', mentions taking a girl to a castle, but the real emergence of Plant's mythological obsessions is found on the acoustic-guitar driven 'Ramble On'. The song is about searching for a girl, and being restless, classical blues tropes and ones that Plant never fails to follow, but the lyrics of the first verse also talk of leaves, rain, the moon, mystical parts of fairy tales. If that is not clear enough, a later verse then says:

Mine's a tale that can't be told, my freedom I hold dear.

How years ago in days of old, when magic filled the air.

T'was in the darkest depths of Mordor, I met a girl so fair.

But Gollum, and the evil one crept up and slipped away with her, her, her... yeah.

The 'days of old, when magic filled the air' are the days of Arthur, King of the Britons. They are also the days of Tolkien's 'Book of Lost Tales', when he perceived our present being the future of the magical England he created (Tolkien 1983, 1984), which 
infused the rest of Tolkien's mythos. Plant confirms we are in Middle-earth with the final two lines, when his narrator tells us of being in the land of Mordor, the evil home of Sauron, the evil one he obviously cites as being in the company of Gollum. In The Hobbit and The Lord of the Rings, Gollum is the pathetic hobbit-like creature who has been corrupted by the power of the One Ring, who Frodo tries to save in the bigger book. Frodo asks Gollum to guide him and his companion Samwise to Mordor, and for many pages Gollum seems to be redeemed. But the power of the Ring is too much for Gollum, who betrays Frodo and Samwise, and ultimately (or fatefully, and happily for the plot) dies when he bites the ring off Frodo's finger and falls into the fires of Mount Doom by accident.

Led Zeppelin III (1970) is dominated by acoustic, folk-rock songs, giving the entire album the vibe of a liminal space. Many of the songs have lyrics that situate the listener in the West, whether that is the north-west of Wales and Snowdonia, or the mythical West of Middle-earth. 'Immigrant Song' is about the Vikings, but these raiders are described as heading for the western shores where fields are green: the Vikings attacked north-west Wales and conquered Anglesey; but the language could be inspired by the hubris of the Numenoreans who sailed for the blessed lands of the West only to be drowned by the gods for their hubris, or the Arthurian tale of Avalon. 'Tangerine' mentions a queen who was Plant's love, who now seems to be a thousand years from him. 'Out On The Tiles' begins with a line about walking along the highway singing a song, tope from the blues that also recalls the 'Walking Song' of the hobbits. This theme returns in 'Bron-y-Aur Stomp', named after the cottage in Wales where Page and Plant stayed. Like many of Plant's lyrics, the inspiration is sexual adventure, but the other material shines through. The lyrics draw on Tolkien's walking song, but draw more obviously from the idea of questing in the Matter of Britain, with some pantheistic reflection thrown in. 
The highlight of Led Zeppelin's career - and the moment when Plant and Page and the others combine to show what they think is authentic through their construction of Englishness and Welshness - is the fourth album, sometimes called Four Symbols but now more usually referred to as Led Zeppelin IV (1971). The original album did not have a name, or the name of the band, anywhere on it. Instead above the list of songs were four symbols, each representing one band member, and all polyvalent - with the weird 'Zoso' symbol for Page. The album originally came with a gatefold cover that included a strange image of an old man standing at the top of mountain, holding a lamp and a staff. The man wears robes, and the landscape looks like the stylized landscapes favoured by Tolkien in his own drawings of Middle-earth and Beleriand. Rumours then and now passed along fans convinced the image is Gandalf from The Lord of the Rings, or perhaps one of the other five wizards of Tolkien's mythology (Fast 2001). Tolkien's pictures show elves carrying similar lamps, and the staff must be a wizard's staff. The truth is stranger still: it is the Hermit from a Tarot card, a figure important to Jimmy Page's own occult dabbling and performativity, who is present in the Led Zeppelin film The Song Remains The Same (Clifton and Massot 1976). However, it is the effect of the image that matters, rather than its actual meaning to Page and the band: it is something uncanny, something that could equally be the Merlin from the Matter of Britain, or Saruman, someone not of this world but perhaps not pure, either. At the bottom of the mountain there is a man, perhaps a pilgrim, who seems to be heading up to see the strange Hermit figure. Behind him is a fantasy medieval landscape, absent of any sign of agriculture, absent of any animals or humans. In the distance there is a late-medieval town, with stone walls, and a castle. The image is designed to evoke a faux-medieval, fantastical place that is yet of the West, of this profane word.

The effect of the image was magnified when listeners put the needle down on their albums, and when they started reading the song titles, and when - later - fans managed to 
swap the lyrics with each other. The album begins with the blues-based 'Black Dog', but the lyrics have no mention of this strange animal. Is the black dog the Black Dog of English folklore, the one that haunts graveyards and wild moors? The next song is a fast heavy rock song made for playing live, and it banishes the black dog from our thoughts and clears our minds for the next two long songs, the most important songs in Led Zeppelin's medievalism: 'Battle of Evermore', and 'Stairway to Heaven'. In both songs, John Paul Jones adds acoustic folk instrumentation - mandolin in the first and recorder in the second - to evoke English folk music, and the spooky medieval folk-rock vibe perfected at the time by Fairport Convention, Mister Fox and others (Gracyk 2007; Winick 2004). If borrowing Fairport Convention's instrumentation is not enough, Led Zeppelin actually borrow Sandy Denny, the band's singer, to provide haunting backing vocals on 'Battle of Evermore'.

Evermore is clearly some magical land that has always existed, and will always exist. It could be the Undying Lands of Tolkien's mythology, or even Middle-earth itself seen as a place of struggle over the future of the eternal, blessed lands of the West. The lyrics also mention 'the angels of Avalon', the blessed and immortal island to the west of Britain, to which King Arthur is taken after he falls in his final battle. Plant wants us to think Avalon and the Undying Lands are the same place, that there is a deeper pagan truth about Tolkien's myths and the British myths. The song begins with a reference to the 'Queen of Light', perhaps a Celtic goddess or one of the gods of Tolkien's Undying Lands. She seems to be one of 'the angels of Avalon' preparing to defend the land from the 'Dark Lord', who could be a pagan war-god whose 'face is red', or who could be Sauron or Morgoth from Tolkien's mythology. The song tells us in Evermore 'the apples of the valley hold the seeds of happiness', recalling the notion that Avalon is named for apples, and apples have a sacred role in Celtic and other European cultures: which suggests Plant may have been reading The Golden Bough by J. G. Frazer (1922), who made the audacious claim that all European 
customs and traditions are remnants of an older pagan magic and religion of human sacrifice that guaranteed the return of the sun. The Dark Lord's presence in Evermore poisons the apples and the battle begins, invisible in the skies above normal mortals (a common trope in folk stories) as well as in Evermore itself. As the music gets more dramatic, the lyric changes its focus to an actual battle field, with a castle whose walls are being shaken by the drums of its attackers, where Plant tells us 'the ring wraiths ride in black' - the first clear reference to characters from The Lord of the Rings, the nine men turned into deathless wraiths by possession of the Nine Rings for Men, in thrall to Sauron and the One Ring. Moments later Plant sings about 'magic runes' made of gold that will 'bring the balance back', which could be from Frazer and from Celtic mythology, though it is interesting to note that the Balance is a concept in the work of Michael Moorcock, the English fantasy author who was becoming well-known at the time. The song ends by telling us that the sun has returned, and the dragon of darkness is blinded by sunlight.

As if one amazing journey through a magical Britain was not enough, 'Stairway to Heaven' is even more epic in length, in musical complexity, and in in its medievalist mythical polyvalent readings. The opening parts of the song are slow and driven by the recorder, then, after the rock instruments have joined in, there is an incredible build-up followed by Jimmy Page's magical guitar solo, which then leads into the grand final stage. It truly is one of the best rock songs of all time. But it is the lyrics that attract our attention. Plant tells us about a mysterious lady who is sure 'all that glitters is gold', who wants to buy this 'stairway to heaven'. He teases us by telling us about a 'sign', warning us that 'words have two meanings'. Then we are in a mythical landscape with a 'tree by the brook', where there is a bird singing. We seem to be in the Undying Lands or Avalon again, and Plant says it makes him 'wonder'. The next verse needs citing in full: 
There's a feeling I get when I look to the west,

And my spirit is crying for leaving.

In my thoughts I have seen rings of smoke through the trees,

And the voices of those who stand looking.

The first two lines of the verse sum up Plant's childhood, reading about RomanoBritish history, figuratively looking to the west of England and thinking about the hills of Wales. It is the older Plant reading the Matter of Britain and looking west towards Avalon, perhaps sitting on the beach at Barmouth, a popular tourist town in north-west Wales on the railway line from Birmingham. It is Plant imagining himself to be in Middle-earth itself, on the shoreline of Gondor with Legolas, staring with him out west to feel the call of the Undying Lands, and the passing of the elves into the sunset. 'Rings of smoke' are the rings blown by pipe-smokers, a favourite habit of hobbits, dwarves and Gandalf in Tolkien's work, and the people looking and talking may well be the humans ('Men' in Tolkien) of the West who watch as the elves and the other races pass through, and pass out of history. In the next verse Plant tells us that 'if we all call the tune' of the 'piper' - if we do the right ritual, believe and do the right thing - then a 'new day will dawn' for those who have been standing 'long', and the 'forest will echo with laughter', presumably the laughter of elves who live in the trees in Tolkien and in English and Welsh folk-lore.

Next, Plant tells us that if we hear some noise in the hedgerow it is just a 'spring clean for the May Queen', the start of the new cycle, the resurrection Frazer claims is at the heart of all European myths. Here Plant has moved beyond Tolkien but he is still drawing from the Matter of Britain, in particular the Welsh Arthurian tales of The Mabinogion, which tell us of Blodeuwedd, the maid made of flowers, who seems to be some sort of spring goddess or nature spirit (Davies 2007). Plant moves us towards the climax by seemingly talking to his 
mysterious vain lady when he tells her there are two paths to follow, and she has still time to pick the right one - the one that follows the 'piper'. The song then reaches its climax, with lines telling us about our journey along the road, where 'there walks a lady we all know, who shines white light who wants to show' the truth to us. On the surface, this is the same lady who wants to buy her stairway to heaven, but the lines read like this woman is the May Queen, or Galadriel the Elf Queen in The Lord of the Rings, someone who is wise and who will show us the right way to the truth. This may be deliberate ambiguity by Plant, or it may be that he just chose got confused accidentally: the impact is the listeners are left furiously debating the song's meaning even now on fan-sites across the internet.

This is not quite the end for Middle-earth on Led Zeppelin IV. The first song on the second side is called 'Misty Mountain Hop', and includes the punchline where Plant tells us he is 'packing his bags for the Misty Mountains, where the spirits go now'. The Misty Mountains are the mountains that run from the cold northern regions of Middle-earth down to Saruman's tower of Orthanc at Isengard. They are the mountains where Bilbo finds the One Ring in The Hobbit when he encounters Gollum, and the mountains under which the Fellowship of Ring travel, when they pass through the dwarven realm of Moria. They are not a good place to go on holiday, but Plant is so exasperated by the 'pressure' of modern life (as recounted in the song) that they suddenly look okay. But that is the last of the medievalism, Middle-earth and the Matter of Britain for the album. And in fact the band never come close to the matter on any of their other albums. On the next album, Houses of the Holy (1973), 'Over the Hills and Far Away' mentions 'pocketful of gold' and 'the open road', but the phrases could have been taken from anywhere; and 'The Rain Song' mentions 'springtime' and the 'wonder of devotion', but it is a love song. Finally, on Physical Graffiti (1975), 'In the Light' says 'in the light you will find the road', but again, this is a love song, and the inspiration is not obviously Malory or Tolkien. 
The only other work of the band that plays with these medievalist tropes is the film The Song Remains the Same (Clifton and Massot 1976). The film combines live footage of the band performing songs at sell-out concerts, with backstage scenes shot in documentary style, band members at home getting news of the tour dates and having awkward fun, and dramatic recreations of the band members' fantasies. For Robert Plant's 'home' scenes, he is found next to a stream in Snowdonia, in north-west Wales, watching his children splash about. This is where he wants us to see him at his most relaxed, the sound of children's laughter merging with the water and the sound of sheep bleating. The camera's positioning allow Wales to be recreated as Middle-earth, without any sign of modern civilization, with mountains looming up above rich, green pastures. This is culture-as-leisure as tourist trip and fantasy. In the fantasy sequence, Plant is a knight from Camelot, or a ranger from The Lord of the Rings, searching for and saving a beautiful young maiden from bad guys in a medieval castle. The scenes were shot in an actual castle in Wales, and the beach at Aberdovey, near Barmouth. This sequence shows us that Plant is embodied in Wales, and Wales is his Avalon, as he acts out the ideal of a questing knight. But Wales is also his Middle-earth, because it is the land between realms, the land he has constructed in is head as his home, the land he needs to defend and own. In these fantasy scenes, Plant is moving from Arthurian quest to sexual conquest, or, perhaps more accurately, Plant's heroic warrior masculinity is running parallel with his own un-bridled heteronormative sexuality in the public sphere (Fast 1999, 2001).

\section{Discussion}

Led Zeppelin's songs and Tolkien's stories are products of popular culture, but they can be understood as culture-as-leisure. They were made by their creators in their leisure time to make sense of their own views about identity. They were then embraced by listeners and readers who wanted to identify with them, and with the myths of identity and masculinity in 
them. Leisure studies, the sociology of leisure and popular music studies are of course filled with similar examples of culture and leisure shaping national identity and masculinity (see for example: Fast 1999; Gruneau and Whitson 1993; Hill 2014; Spracklen 2014, 2015, 2017; Watson and Scraton 2013).

Led Zeppelin emerged at a time when the problem of Great Britain - what it means to be British, or English, or Welsh - was becoming pressing as the last of the British Empire's colonies were given their independence. Great Britain in the 1960s was more pessimistic as a nation-state than Great Britain at the end of the Second World War (Darwin 2009). The idea that 'Britannia rules the waves' had been overturned in the Second World War, when it became clear that the future world order would be dominated by the United States of America and the Soviet Union. This was the time of increased numbers of migrants coming to work in Great Britain, the moment when white people started to argue forcefully that Britain was their home, and not the home of people who were not white (Holmes 2015). This British or English white nationalism was based on myths of belonging and blood, but it entered mainstream politics (Darwin 2009; Holmes 2015). In the 1950s, Great Britain still clung onto the myth of its own importance and status as an imperial, global power, and although it retained a permanent seat on the United Nation' Security Council it survived through embracing American and supporting American interests. The failure of British aims in the Suez Crisis revealed Great Britain to be a post-imperial nation-state, and many people in Great Britain turned to the past to find a more magical place where the island was still important. The history of Britain in this period became even more contested than before. English people tried to define an Englishness based on race and nation, invented tradition and imaginary community. This was often British nationalism, so populist in its focus that it identified England with Britain and Britain with England (Kumar 2003). 
Gwyn A. Williams (1985) has demonstrated the invented and imagined nature of Welsh identity. Wales historically was defined by its bigger neighbour England (Wales is Old English for the land of the foreigners). Welsh nationalism emerged in the modern era built on a historiography conflating Arthurian tales of British kings fighting the evil Saxons, the resistance campaigns of medieval princes and Owain Glyndwr, non-conformity and the chapel, and half-remembered and reconstructed poems in the Welsh language. In most of the twentieth century, the modern Welsh Nationalists drew their support from Welsh-speaking communities in the rural north-west of Wales, which is still the political heartland for Plaid Cymru, the Welsh nationalist party. In the 1960s, Welsh nationalism was beginning to become radical, changing from preserving the language and customs to demanding devolution of political powers or full independence. Some Welsh nationalists in this period even started to call for direct action: mass protests over road-signs, and burning down cottages bought by rich English in-comers or holiday-makers (Jones and Merriman 2009). All of this nationalism was legitimated through the social construction of medieval history, and the re-working of traditions in popular culture. Tolkien was the most influential of those re-workers of English and Welsh history, even if the Welsh part of his mythology was restricted to the language and some Arthurian and Celtic themes echoed very faintly in the published work (Fimi 2008). The work of Led Zeppelin draws upon both the work of Tolkien and the Arthurian traditions to construct ideas of masculine belonging in some mythological medieval time and place: this place is a conflation of Middle-earth and the Undying lands from Tolkien, Camelot and Avalon from Arthur in fiction and quite probably in film, and Wales and post-Roman Britannia as seen from the West Midlands. While this construction is idiosyncratic to the artists, and especially to the singer Robert Plant, the band collectively are drawing on and justifying the wider problem of England, Wales and Britain, to make sense of their place in Great Britain in the new Dark Ages of the late twentieth 
century. And this collective idea of Wales-Avalon-Middle-earth-England-Britain - with its performed masculinity - continues to be re-produced as fans continue to listen to the music, or watch the film, and as critics continue to write about the band.

\section{Conclusion}

This inter-disciplinary exploration of memory, identity and belonging in culture-as-leisure shows the continuing long shadow of the Matter of Britain. Tourists still visit North Wales to see the beaches overshadowed by the misty mountains of Snowdonia. People still watch films based on Tolkien's books, and still read the books; they still meet at fan conventions and online to comment on the connection between Middle-earth and the spaces and history of the British Isles (Piatti-Farnell 2015). And people still listen to Led Zeppelin's songs as a way of finding their way from Glastonbury Tor to Avalon. The popular memory of Britain, Wales and England in the Dark Ages is subject to a construction of belonging that is not simply hegemonic, though it draws from the standard histories. Culture-as-leisure, then, is a continuing space for meaning-making and identity construction. Popular culture is always a contestation between communicative leisure and instrumental leisure (Spracklen 2009), where hegemonic power can be resisted for a moment, but where hegemony shapes myths and identity so much that the instrumental constructions become taken-for-granted truths about nation and gender.

\section{References}

Adorno, T. (1991). The culture industry. London: Routledge.

Alexander, M. (2007). Medievalism: The middle ages in modern England. New York: Yale University Press. 
Armstrong, D., \& Hodges, K. (2014). Mapping Malory: Regional identities and national geographies in Le Morte D'arthur. Basingstoke: Palgrave.

Aronstein, S., \& Coiner, N. (1994). Twice knightly: Democratizing the middle ages for middle-class America. Studies in Medievalism, VI, 212-231.

Barber, R. (2002). King Arthur in music. Cambridge: D. S. Brewer.

Barczewski, S. (2000). Myth and national identity in nineteenth-century Britain: The legends of King Arthur and Robin Hood. Oxford: Oxford University Press.

Batt, C. (2016). Malory's Morte D’Arthur: Remaking Arthurian tradition. London: Palgrave.

Bloch, R. H. (1993). The once and future middle ages. Modern Language Quarterly, 54(1), $67-77$.

Bloch, R. H., \& Nichols, S. G. (Eds.). (1996). Medievalism and the modernist temper. Baltimore: John Hopkins University Press.

Brackett, J. (2008). Examining rhythmic and metric practices in Led Zeppelin's musical style. Popular Music, 27(1), 53-76.

Burges, J. (2013). We are all geeks now: Fantasy as a mode of social practice in disenchanted modernity. Twentieth Century Literature, 59(3), 494-504. 
Cantor, N. F. (1991). Inventing the middle ages. New York: Quill William Morrow.

Carpenter, H. (1977). Tolkien: A biography. London: Allen and Unwin.

Clifton, P., \& Massot, J. (Dirs.). (1976). The song remains the same. London: Swan Song.

Connell, R. (1987). Gender and power. Stanford: Stanford University Press.

Connell, R. (1995). Masculinities. Cambridge: Polity.

Darwin, J. (2009). The empire project: The rise and fall of the British world-system, 18301970. Cambridge: Cambridge University Press.

Davies, S. (2007). The Mabinogion. Oxford: Oxford University Press.

Fast, S. (1999). Rethinking issues of gender and sexuality in Led Zeppelin: A woman's view of pleasure and power in hard rock. American Music, 17(3), 245-299.

Fast, S. (2001). In the houses of the holy: Led Zeppelin and the power of rock music. Oxford: Oxford University Press.

Fimi, D. (2008). Tolkien, race and cultural history: From fairies to hobbits. Basingstoke: Palgrave Macmillan. 
Finke, L. A., \& Shichtman, M. B. (2010). Cinematic illuminations: The middle ages on film. Baltimore: Johns Hopkins University Press.

Frazer, J. G. (1922). The golden bough: A study in magic and religion. London: Macmillan.

Gracyk, T. (2007). Listening to popular music, or, how I learned to stop worrying and love Led Zeppelin. Ann Arbor: University of Michigan Press.

Gruneau, R., \& Whitson, D. (1993). Hockey Night in Canada: Sport, Identities and Cultural Politics. Toronto: Garamond Press.

Hale, A. (2001). Representing the Cornish: Contesting heritage interpretation in Cornwall. Tourist Studies, 1(2), 185-196.

Higham, N. J. (2005). King Arthur: Myth-making and history. Abingdon: Routledge.

Hill, R. L. (2014). Reconceptualizing hard rock and metal fans as a group: Imaginary community. International Journal of Community Music, 7(2), 173-87.

Holmes, C. (2015). John Bull's island: Immigration and British society, 1871-1971. London: Routledge.

Ingham, P. C. (2015). Sovereign fantasies: Arthurian romance and the making of Britain. Philadelphia: University of Pennsylvania Press. 
Jackson, K. H. (1969). The Gododdin: The oldest Scottish poem. Edinburgh: Edinburgh University Press.

Jones, R., \& Merriman, P. (2009). Hot, banal and everyday nationalism: Bilingual road signs in Wales. Political Geography, 28(3), 164-173.

Kandt, J., Cheshire, J. A., \& Longley, P. A. (2016). Regional surnames and genetic structure in Great Britain. Transactions of the Institute of British Geographers, 41(4), 554-569.

Kumar, K. (2003). The making of English national identity. Cambridge: Cambridge University Press.

Led Zeppelin. (1969a). Led Zeppelin. New York: Atlantic Records.

Led Zeppelin. (1969b). Led Zeppelin II. New York: Atlantic Records.

Led Zeppelin. (1970). Led Zeppelin III. New York: Atlantic Records.

Led Zeppelin. (1971). Led Zeppelin IV. New York: Atlantic Records.

Led Zeppelin. (1973). Houses of the Holy. New York: Atlantic Records.

Led Zeppelin. (1975). Physical Graffiti. London: Swan Song Records. 
LeGreco, M., \& Tracy, S. (2009). Discourse tracing as qualitative practice. Qualitative Inquiry, 15(9): 1516-1543.

Mathijs, E. (2006). The Lord of the Rings: Popular culture in global context. New York: Wallflower Press.

Parker, S. (1971). The future of work and leisure. London: MacGibbon and Kee.

Piatti-Farnell, L. (Ed.). (2015). Fan phenomena: The Lord of the Rings. Bristol: Intellect.

Rateliff. J. (2007). The history of The Hobbit. London: HarperCollins.

Robb, J. G. (1998). Tourism and legends: Archaeology of heritage. Annals of Tourism Research, 25(3), 579-596.

Rosebury, B. (2003). Tolkien: A cultural phenomenon. Basingstoke: Palgrave Macmillan.

Schwarz, B. (Ed.). (2005). The expansion of England: Race, ethnicity and cultural history. Abingdon: Routledge.

Shippey, T. A. (1982). The road to Middle-earth. London: Allen and Unwin.

Spracklen, K. (2009). The meaning and purpose of leisure: Habermas and leisure at the end of modernity. Basingstoke: Palgrave Macmillan. 
Spracklen, K. (2011). Constructing leisure: Historical and philosophical debates.

Basingstoke: Palgrave Macmillan.

Spracklen, K. (2013). Whiteness and leisure. Basingstoke: Palgrave Macmillan.

Spracklen, K. (2014). There is (almost) no alternative: The slow 'heat death' of music subcultures and the instrumentalization of contemporary leisure. Annals of Leisure Research, 17(3), 252-266.

Spracklen, K. (2015). To Holmgard... and beyond: Folk metal fantasies and hegemonic white masculinities. Metal Music Studies, 1(3), 354-377.

Spracklen, K. (2017). Bravehearts and bonny mountainsides: Nation and history in Scottish folk/black metal. Rock Music Studies, 4(2), 102-116.

Tolkien, J. R. R. (1937). The Hobbit: or There and Back Again. London: George Allen and Unwin.

Tolkien, J. R. R. (1954a). The Fellowship of the Ring: being the first part of The Lord of the Rings. London: George Allen and Unwin.

Tolkien, J. R. R. (1954b). The Two Towers: being the second part of The Lord of the Rings. London: George Allen and Unwin. 
Tolkien, J. R. R. (1956). The Return of the King: being the third part of The Lord of the Rings. London: George Allen and Unwin.

Tolkien, J. R. R. (1977). The Silmarillion. London: George Allen and Unwin.

Tolkien, J. R. R. (1983). The Book of Lost Tales, Part I (The History of Middle-earth: Vol. 1). London: George Allen and Unwin.

Tolkien, J. R. R. (1984). The Book of Lost Tales, Part II (The History of Middle-earth: Vol. 2). London: George Allen and Unwin.

Tolkien, J. R. R. (1985). The Lays of Beleriand (The History of Middle-earth: Vol. 3). London: George Allen and Unwin.

Tolkien, J. R. R. (1986). The Shaping of Middle-earth (The History of Middle-earth: Vol. 4). London: George Allen and Unwin.

Tolkien, J. R. R. (1987). The Lost Road and Other Writings (The History of Middle-earth: Vol. 5). London: Unwin Hyman.

Watson, B., \& Scraton, S. (2013). Leisure studies and intersectionality. Leisure Studies, $32(1), 35-47$.

Wickham, C. (2005). Framing the early middle ages: Europe and the Mediterranean, 400800. Oxford: Oxford University Press. 
Williams, G. A. (1985). When was Wales? A history of the Welsh. Harmondsworth: Penguin.

Winick, S. D. (2004). A. L. Lloyd and Reynardine: Authenticity and authorship in the afterlife of a British broadside ballad. Folklore, 115(3), 286-308. 